\title{
PENGARUH MANAJEMEN LABA DAN KARAKTERISTIK PERUSAHAAN TERHADAP TAX AVOIDANCE
}

\author{
Henny \\ Jurusan Akuntansi, Universitas Tarumanagara Jakarta \\ Email: henny@fe.untar.ac.id
}

Masuk : 01-02-2019, revisi: 03-15-2019, diterima untuk diterbitkan : 30-04-2019

\begin{abstract}
ABSTRAK
Penghindaran pajak adalah upaya yang dilakukan oleh perusahaan untuk menghemat pembayaran pajak yang dapat dilakukan secara legal. Tujuan dari penelitian ini adalah untuk memperoleh bukti empiris tentang pengaruh manajemen laba dan karakteristik perusahaan terhadap penghindaran pajak pada perusahaan manufaktur di Bursa Efek Indonesia untuk periode 2014-2016. Populasi dalam penelitian ini adalah perusahaan yang terdaftar di Bursa Efek Indonesia, dengan sampel perusahaan manufaktur yang memenuhi kriteria penelitian sebanyak 69 perusahaan sampel menggunakan metode purposive sampling. Penelitian ini menggunakan manajemen laba dan karakteristik perusahaan sebagai variabel independen dan penghindaran pajak sebagai variabel dependen. Analisis yang digunakan dalam penelitian ini adalah analisis regresi linier berganda. Hasil penelitian ini adalah salah satu karakteristik perusahaan, yaitu leverage berpengaruh positif terhadap penghindaran pajak, sedangkan ukuran dan intensitas modal yang merupakan karakteristik perusahaan dan manajemen laba tidak mempengaruhi penghindaran pajak.
\end{abstract}

Kata Kunci: Manajemen Penghasilan, Karakteristik Perusahaan, Leverage, Penghindaran Pajak

\begin{abstract}
Tax avoidance is an effort made by the company to save tax payments that can be done legally. The purpose of this study is to obtain empirical evidence about the effect of earnings management and firm characteristics on tax avoidance in manufacturing companies in the Indonesia Stock Exchange for the period 2014-2016. The population in this study are companies listed on the Indonesia Stock Exchange, with a sample of manufacturing companies that meet the research criteria as many as 69 sample companies using purposive sampling method. This study uses earnings management and firm characteristics as independent variables and tax avoidance as the dependent variable. The analysis used in this study is multiple linear regression analysis. The results of this study are one of the firm characteristic, that is leverage has a positive effect on tax avoidance, while the size and capital intensity which is the firm characteristic and earnings management does not affect tax avoidance.
\end{abstract}

Keywords: Earnings Management, Firm Characteristic, Leverage, Tax Avoidance

\section{PENDAHULUAN}

\section{Latar Belakang}

Sumber penerimaan negara Indonesia dari masyarakat adalah pajak. Hal ini dikarenakan pajak merupakan iuran rakyat yang wajib dibayar oleh wajib pajak orang pribadi maupun badan. Pembayaran pajak yang dilakukan oleh wajib pajak badan adalah hal yang selalu dihindari dikarenakan dapat mengurangi laba bersih yang diperoleh selama satu tahun. Strategi yang dipakai oleh perusahaan dalam mengatasi pengurangan laba bersih yang terkait dengan pajak yang besar, maka perusahaan berusaha meminimalkan pajak melalui pengelolaan pajak secara legal yang biasa disebut penghindaran pajak (tax avoidance). Tax avoidance ini dilakukan dengan cara merekayasa pajak yang masih dalam batasan undang-undang pajak. Tindakan penghindaran pajak atau agresif dalam perpajakan dilakukan karena adanya kesempatan dan peluang yang dilihat oleh perusahaan sebagai wajib pajak badan yaitu lemahnya peraturan dan undang-undang terkait perpajakan dan kelemahan dari sumber daya manusia (fiskus). Tindakan 
tax avoidance akan menyebabkan penerimaan negara dari pajak akan menurun di Anggaran Pendapatan dan Belanja Negara (Putra \& Merkusiwati, 2016).

Salah satu faktor yang dapat mempengaruhi perusahaan melakukan tax avoidance adalah manajemen laba. Perusahaan cenderung melakukan manajemen laba dengan cara income decreasing sebagai upaya tax avoidance, dimana semakin besar income decreasing yang dilakukan maka perusahaan tersebut juga terindikasi berperilaku tax avoidance. Pengaruh manajemen laba berupa income decreasing terhadap tax avoidance perusahaan merupakan laba yang menjadi patokan untuk mengukur besarnya beban pajak perusahaan. Oleh karena itu, manajemen akan melaporkan laba disesuaikan dengan tujuannya yaitu menggunakan pilihan akuntansi yang mengurangi laba atau income decreasing sebagai bentuk tax avoidance. Bila perusahaan semakin besar melakukan income decreasing maka semakin kecil pajak yang harus dibayarkan perusahaan (Suyanto \& Supramono, 2012). Praktek earnings management dilakukan perusahaan sebagai alat untuk melakukan penghindaran regulasi pemerintah (political cost hypothesis). Salah satu regulasi pemerintah yang berkaitan langsung dengan laba perusahaan adalah pajak penghasilan badan (Badertscher et al., 2009).

Karakteristik perusahaan juga merupakan faktor yang mempengaruhi perusahaan melakukan tax avoidance. Karakteristik perusahaan ini terdiri dari leverage, size dan capital instensity. Dharma dan Ardiana (2016) dalam penelitiannya menunjukkan bahwa leverage dan capital intensity berpengaruh negatif terhadap tax avoidance, yang berarti semakin tinggi tingkat leverage dan capital intensity akan menyebabkan menurunnya tax avoidance. Size perusahaan berpengaruh positif terhadap tax avoidance, yang berarti semakin tinggi size perusahaan maka akan menyebabkan tingginya tax avoidance. Leverage dalam penelitian Putra dan Merkusiwati (2016) serta Ngadiman dan Puspitasari (2014) menunjukkan hasil yang berbeda, bahwa leverage tidak berpengaruh terhadap tax avoidance. Size perusahaan juga menunjukkan hasil yang berbeda dalam penelitian Dewi et al. (2016), serta Dewi dan Jati (2014) yaitu size perusahaan tidak berpengaruh terhadap tax avoidance. Begitu pula dengan capital intensity menunjukkan bahwa tidak ada pengaruh terhadap tax avoidance, hal ini ditunjukkan dari penelitian Putra dan Merkusiwati (2016), Siregar dan Widyawati (2016), dan Dewi et al. (2016).

Berdasarkan perbedaan hasil inilah diperlukan penelitian ulang untuk memastikan adanya pengaruh Manajemen Laba dan Karakteristik Perusahaan terhadap Tax Avoidance. Oleh karena itu tujuan penelitian ini adalah untuk memperoleh bukti empiris mengenai 1) Manajemen Laba berpengaruh positif terhadap Tax Avoidance; 2) Karakteristik Perusahaan berpengaruh positif terhadap Tax Avoidance, yang terdiri dari: (a) Leverage berpengaruh positif terhadap Tax Avoidance; (b) Size berpengaruh positif terhadap Tax Avoidance; (c) Capital Intensity berpengaruh positif terhadap Tax Avoidance.

\section{Tinjauan Pustaka}

Stakeholder Theory. Dalam teori stakeholder, laba akuntansi merupakan ukuran return bagi pemegang saham (shareholder), sementara value added adalah ukuran yang lebih akurat yang diciptakan oleh stakehoders dan kemudian didistribusikan kepada stakeholders yang sama (Meek \& Gray, 1988). Stakeholder (Siregar \& Widyawati, 2016) adalah pihak-pihak yang mempunyai kepentingan baik langsung maupun tidak langsung, terhadap eksistensi atau aktivitas perusahaan. Stakeholder yang dimaksud meliputi pemegang saham, karyawan, pelanggan, pemasok, kreditor, pemerintah dan masyarakat. Fokus utama dalam teori ini yaitu bagaimana perusahaan memonitor dan merespon kebutuhan stakeholdernya. 
Agency Theory. Teori agensi menyatakan bahwa antara manajemen dan pemilik mempunyai kepentingan yang berbeda (Jensen \& Meckling, 1976). Hubungan principal dan agen sering ditentukan oleh angka akuntansi. Hal ini memacu agen untuk memikirkan bagaimana angka akuntansi tersebut dapat digunakan sebagai sarana untuk memaksimalkan kepentingannya. Terjadinya konflik kepentingan antara principal dan agen kemungkinan akan menimbulkan ketimpangan informasi yang disebut dengan agency theory. Secara empiris, konflik tersebut dapat dibuktikan oleh Watts dan Zimmerman (1986).

Tax Avoidance. Tax avoidance (Siregar \& Widyawati, 2016) adalah usaha yang dilakukan perusahaan untuk menghemat pembayaran pajaknya yang dapat dilakukan dengan cara yang legal yakni penghindaran pajak. Penghindaran pajak (tax avoidance) merupakan legal utilization atau legal arrangements of tax fair's affairs yaitu suatu perbuatan legal dengan memanfaatkan celah dari Undang-Undang Perpajakan untuk meminimalkan beban pajak penghasilan yang seharusnya dibayar.

Manajemen Laba. Manajemen laba (Scott, 2015) sebagai tindakan manajer memilih kebijakan akuntansi atau tindakan yang mempengaruhi pendapatan dalam pelaporan keuangan. Manajemen laba merupakan tindakan mementingkan kepentingan pribadi manajer untuk memaksimalkan utilitas dan kesejahteraannya dalam menjalankan kontrak dengan prinsipal. Informasi perusahaan yang memadai dimiliki manajer dimanfaatkan agar tindakan manajemen laba dapat dilakukan. Ada beberapa motivasi yang mendorong dilakukannya manajemen laba yaitu motivasi pajak, pergantian CEO, penawaran saham perdana, dan motivasi pasar modal

Karakteristik Perusahaan. Karakteristik perusahaan dalam penelitian ini terdiri dari leverage, size dan capital intensity. Leverage (Siregar \& Widyawati, 2016) merupakan tingkat hutang yang digunakan perusahaan dalam melakukan pembiayaan. Leverage menggambarkan tingkat risiko dari perusahaan yang diukur dengan membandingkan total kewajiban perusahaan dengan total aktiva yang dimiliki perusahaan. Semakin besar tingkat hutang yang dimiliki perusahaan maka semakin besar risiko yang akan ditanggung. Size atau ukuran perusahaan merupakan nilai yang mengklasifikasikan perusahaan ke dalam kategori besar atau kecilnya berdasarkan total aset, $\log$ size, dan lain-lain. Semakin besar total aset maka semakin besar pula ukuran perusahaan tersebut. Semakin besar ukuran perusahaan, maka perusahaan akan semakin memanfaatkan celah-celah yang ada, sehingga dapat melakukan tax avoidance (Siregar \& Widyawati, 2016). Capital intensity menurut Siregar dan Widyawati (2016) dapat didefinisikan sebagai perusahaan menginvestasikan asetnya pada aset tetap dan persediaan. Dalam penelitian ini capital intensity diproksikan dengan menggunakan rasio intensitas aset tetap. Intensitas aset tetap adalah seberapa besar proporsi aset tetap perusahaan dalam total aset yang dimiliki perusahaan. Menurut Dharma dan Ardiana (2016) intensitas kepemilikan aset tetap dapat mempengaruhi pembayaran pajak perusahaan. Beban depresiasi yang terdapat dalam kepemilikan aset tetap dapat mempengaruhi jumlah pajak perusahaan.

Berikut pengembangan hipotesis penelitian ini berdasarkan penelitian terdahulu di atas:

\section{Pengaruh Manajemen Laba terhadap Tax Avoidance}

Penelitian Badertsche, et al. (2009) menunjukkan praktek manajemen laba dilakukan oleh perusahaan sebagai alat untuk melakukan penghindaran regulasi pemerintah (political cost hypothesis). Salah satu regulasi pemerintah yang berkaitan langsung dengan laba perusahaan adalah pajak penghasilan badan. Pengaruh manajemen laba berupa income decreasing terhadap agresivitas pajak dengan proksi effective tax rate dapat dijelaskan bahwa laba menjadi patokan 
untuk mengukur beban pajak perusahaan. Oleh karena itu, manajemen akan melaporkan laba disesuaikan dengan tujuannya yaitu menggunakan pilihan akuntansi yang mengurangi laba atau income decreasing sebagai bentuk penghindaran pajak (Suryanto \& Supramono, 2012). Hal ini dapat disimpulkan bahwa semakin besar income decreasing yang dilakukan perusahaan, maka perusahaan tersebut juga terindikasi penghindaran pajak. Berdasarkan penelitian dan analisa di atas, maka hipotesis yang dapat menunjukkan pengaruh Manajemen Laba terhadap Tax Avoidance adalah:

$\mathrm{H}_{1}$ : Manajemen Laba berpengaruh positif terhadap Tax Avoidance

\section{Karakteristik Perusahaan dan Tax Avoidance}

Karakteristik perusahaan yang akan diteliti dalam penelitian ini adalah leverage, size dan capital intensity yang dapat berpengaruh terhadap tax avoidance.

\section{Pengaruh Leverage terhadap Tax Avoidance}

Leverage berpengaruh positif terhadap penghindaran pajak (Siregar \& Widyawati, 2016; Dewi, et al., 2016; Dharma \& Adriana, 2016). Perusahaan manufaktur yang memanfaatkan hutang untuk meminimalkan beban pajak perusahaan bahkan cenderung mengarah agresif terhadap pajak, hal ini dikarenakan perusahaan yang memiliki utang tinggi akan mendapatkan insentif pajak berupa potongan atas bunga pinjaman. Sehingga perusahaan yang memiliki beban pajak tinggi dapat melakukan penghematan pajak dengan cara menambah hutang perusahaan. Hutang yang bertambah guna memperoleh insentif pajak yang besar maka dapat dikatakan bahwa perusahaaan tersebut melakukan penghindaran terhadap pajak. Semakin tinggi leverage perusahaan maka semakin tinggi tindakan penghindaran pajaknya. Berdasarkan penelitian dan analisa di atas, maka hipotesis yang dapat menunjukkan pengaruh Leverage terhadap Tax Avoidance adalah:

$\mathrm{H}_{2}$ : Leverage berpengaruh positif terhadap Tax Avoidance

\section{Pengaruh Size terhadap Tax Avoidance}

Penelitian Darmawan dan Sukartha (2014), Ngadiman dan Puspitasari (2014), Siregar dan Widyawati (2016), Dharma dan Adriana (2016), serta Putra dan Merkusiwati (2016) menunjukkan hasil variabel Size berpengaruh positif terhadap Tax Avoidance. Perusahaan yang melakukan tax avoidance adalah perusahaan yang menghadapi political power theory karena mempunyai sumber daya yang mencukupi untuk memanfaatkan proses politik yang dapat menguntungkan mereka dan melakukan aktivitas perencanaan pajak yang agresif dengan tujuan mendapatkan penghematan pajak melalui penghindaran pajak yang dilakukan. Semakin besar size atau ukuran perusahaan, maka semakin besar tindakan penghindaran pajaknya. Berdasarkan penelitian dan analisa di atas, maka hipotesis yang dapat menunjukkan pengaruh Size terhadap Tax Avoidance adalah:

$\mathrm{H}_{3}$ : Size berpengaruh positif terhadap Tax Avoidance

\section{Pengaruh Capital Intensity terhadap Tax Avoidance}

Aset tetap perusahaan memiliki umur ekonomis yang berbeda-beda apabila dilihat dari perpajakan Indonesia. Aset tetap tersebut juga memiliki beban depresiasi yang berbeda. Oleh karena itu, capital intensity berpengaruh positif terhadap tax avoidance (Dharma \& Ardiana, 2016). Hal ini menunjukkan bahwa intensitas aset tetap berpengaruh positif terhadap effective tax rate (ETR). Semakin besar intensitas aset tetap maka effective tax rate perusahaan juga semakin tinggi. Berdasarkan penelitian dan analisa di atas, maka hipotesis yang dapat menunjukkan pengaruh Capital Intensity terhadap Tax Avoidance adalah: 


\section{$\mathrm{H}_{4}$ : Capital Intensity berpengaruh positif terhadap Tax Avoidance}

Berikut gambar kerangka pemikiran penelitian ini berdasarkan pengembangan hipotesis di atas:

\section{Variabel Independen \\ Variabel Dependen}

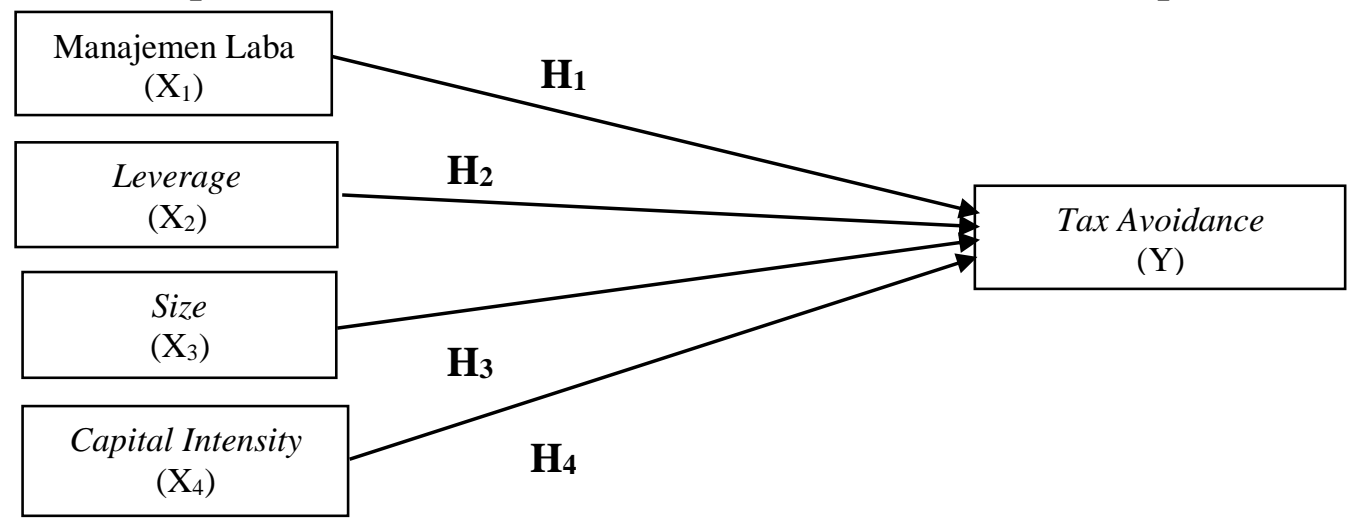

Gambar 1. Kerangka Pemikiran

\section{METODE PENELITIAN}

\section{Populasi dan Sampel}

Sekaran (2008:122) menyatakan populasi merupakan kumpulan semua elemen dalam populasi dimana sampel diambil. Populasi pada penelitian ini adalah perusahaan manufaktur yang terdaftar di Bursa Efek Indonesia pada tahun 2014 sampai 2016.

Sekaran (2008:122) juga menyatakan sampel adalah sebagian dari populasi yang terdiri atas sejumlah anggota yang dipilih dari populasi. Penelitian ini menggunakan teknik sampel tak acak (non probability sampling) yaitu judgement sampling (purposive sampling). Sampel dipilih berdasarkan kondisi khusus yang dianggap mampu mengindikasikan karakter populasi (Daito, 2011: 206). Sampel-sampel tersebut mempunyai karakteristik kunci yang memungkinkan untuk dikaji dan diambil berdasarkan pertimbangan yang bersifat ilmiah. Berikut kriteria yang digunakan: (1) Sampel adalah perusahaan manufaktur yang terdaftar di Bursa Efek Indonesia pada periode 2014-2016; (2) Sampel tidak membukukan rugi berturut-turut dalam periode 20142016; (3) Sampel memiliki data lengkap laporan keuangan yang telah diaudit periode 20142016.

\section{Operasionalisasi Variabel}

Operasionalisasi variabel dalam penelitian ini adalah

1. Variabel Dependen (Y)

Penelitian ini menggunakan Tax Avoidance sebagai variabel dependen, dengan menggunakan pengukuran Effective Tax Rate (Gupta \& Newberry, 1997).

$$
\text { Effective Tax Rate }(\mathrm{ETR})=\underset{\text { Laba Sebelum Pajak }}{\frac{\text { Beban Pajak }}{}}
$$

ETR merupakan efektifitas pembayaran pajak yang dilakukan oleh perusahaan. Jika meminimalkan beban pajak yang seharusnya dibayar, maka perusahaan melakukan Tax Avoidance. Variabel ini merupakan variabel yang menggunakan skala rasio dan bersumber dari laporan keuangan perusahaan manufaktur yang terdaftar di Bursa Efek Indonesia periode 20142016. 
2. Variabel Independen $(X)$

Variabel independen dalam penelitian ini adalah Manajemen Laba dan Karakteristik Perusahaan yang terdiri dari Leverage, Size dan Capital Intensity.

a. Manajemen Laba (Earning Management)

Manajemen Laba dalam penelitian ini diukur dengan nilai discretionary accrual (DA). Penggunaan discretionary accrual sebagai proksi manajemen laba dihitung dengan modified jones model (Dechow et al., 1995).

$$
\text { DAit }=\frac{\text { TAit }}{\text { Ait }-1} \text { ND Ait }
$$

Pengukuran manajemen laba modified jones model di atas dihitung dengan cara sebagai berikut:

$$
\mathrm{TA}_{\mathrm{it}}=\mathrm{NI}_{\mathrm{t}}-\mathrm{CFO}_{\mathrm{it}}
$$

Nilai total accruals (TA) diestimasi dengan persamaan regresi linear berganda yang berbasis Ordinary Least Square (OLS) sebagai berikut:

$$
\frac{\mathrm{TAit}}{\text { Ait-1 }}=\beta 1 \frac{(1)}{\text { Ait-1 }}+\beta 2 \underset{\text { Ait-1 }}{(\Delta \mathrm{Rev})}+\beta 3\left(\frac{\mathrm{PPEt}}{\text { Ait }}\right)
$$

Dengan menggunakan koefisien regresi diatas nilai non discretionary accruals (NDA) dapat dihitung dengan rumus:

$$
\begin{aligned}
& \text { NDAit }=\beta 1 \underline{(1)}+\beta 2(\underline{\operatorname{Rev}}-\underline{\Delta \mathrm{Rec}})+\beta 3(\underline{\mathrm{PPEt}}) \\
& \text { Ait-1 Ait-1 Ait-1 Ait-1 }
\end{aligned}
$$

Keterangan : DAit $\quad=$ Discretionary Accruals perusahaan i pada periode ke t;

NDAit $=$ Non Discretionary Accruals perusahaan i pada periode ke t;

TAit $\quad=$ Total akrual perusahaan i pada periode ke $\mathrm{t}$;

Nit = Laba bersih perusahaan i pada periode ke-t;

CFOit = Aliran kas dari aktivitas operasi perusahaan i pada periode ke $\mathrm{t}$;

Ait-1 = Total aktiva perusahaan i pada periode ke $\mathrm{t}-1$;

$\Delta \mathrm{Rev}=$ Perubahan pendapatan perusahaan $\mathrm{i}$ pada periode ke $\mathrm{t}$;

PPEt = Aktiva tetap perusahaan pada periode ke $\mathrm{t}$;

$\Delta \mathrm{Rec}=$ Perubahan piutang perusahaan $\mathrm{i}$ pada periode ke $\mathrm{t}$;

e $\quad=$ error

b. Karakteristik Perusahaan

Karakteristik perusahaan terdiri dari:

1) Leverage. Leverage menggambarkan tingkat risiko dari perusahaan yang diukur dengan membandingkan total hutang perusahaan dengan total aset yang dimiliki perusahaan (Dharma \& Ardiana, 2016).

$$
\text { LEV }=\frac{\text { Total Hutang }}{\text { Total Aset }}
$$

2) Size. Size atau ukuran perusahaan merupakan tingkat ukuran besar kecilnya suatu perusahaan yaitu berdasarkan total aset yang dimiliki oleh perusahaan (Siregar \& Widyawati, 2016). Total aset digunakan untuk pengukuran Size karena total aset relatif lebih stabil dibandingkan dengan total penjualan. Total aset memiliki satuan angka paling besar, hal ini dapat menimbulkan heteroskedastisitas sehingga dapat ditransformasikan ke log natural (Ln).

$$
\mathrm{SIZE}=\operatorname{Ln}(\text { Total Assets })
$$

3) Capital Intensity. Capital Intensity merupakan gambaran banyaknya investasi perusahaan terhadap aset tetap perusahaan (Dharma \& Ardiana, 2016). 


$$
\mathrm{CAP}=\frac{\text { Total Aset Tetap }}{\text { Total Aset }}
$$

Variabel ini merupakan variabel yang menggunakan skala rasio dan bersumber dari laporan keuangan perusahaan manufaktur yang terdaftar di Bursa Efek Indonesia periode 2014-2016.

\section{Analisis Data}

Analisis data ini dimulai dari teknik pengolahan data yang dilakukan dengan menggunakan alat bantu statistik SPSS yaitu: 1) Uji Statistik Deskriptif; 2) Uji Normalitas; 3) Uji Asumsi Klasik. Selanjutnya teknik pengujian hipotesis yang dilakukan dalam penelitian ini: 1) Uji Statistik F; 2) Uji Statistik t; 3) Koefisien Determinasi. Pada penelitian ini, yaitu hipotesis $1 \mathrm{~s} / \mathrm{d} \quad 4$ menggunakan analisis regresi berganda dengan model sebagai berikut:

$$
\begin{aligned}
& \mathrm{ETR}=\alpha+\beta_{1} \mathrm{EM}+\beta_{2} \mathrm{LEV}+\beta_{3} \mathrm{SIZE}+\beta_{4} \mathrm{CAP}+\mathrm{e} \\
& \text { Keterangan: ETR = Effective Tax Rate untuk variabel Tax Avoidance } \\
& \mathrm{EM}=\text { Earnings Management } \\
& \text { LEV = Leverage } \\
& \text { SIZE } \quad=\text { Size } \\
& \text { CAP } \quad=\text { Capital Intensity } \\
& \alpha \quad=\text { Konstanta; } \\
& \beta_{1}, \beta_{2}, \beta_{3}, \beta_{4}=\text { Koefisien regresi dari setiap variabel independen } \\
& \text { e } \quad=\text { Error }
\end{aligned}
$$

\section{HASIL DAN PEMBAHASAN}

\section{Gambaran Umum Objek Penelitian}

Populasi yang digunakan dalam penelitian ini adalah perusahaan manufaktur yang terdaftar di Bursa Efek Indonesia tahun 2014 s/d 2016. Pengambilan sampel dilakukan dengan metode purposive sampling. Jumlah perusahaan manufaktur yang terdaftar di Bursa Efek Indonesia selama tahun 2014 s/d 2016 adalah 148 perusahaan. Berdasarkan data yang diperoleh, perusahaan manufaktur yang memenuhi kriteria dalam penelitian ini adalah sebanyak 69 perusahaan. Dengan menggunakan data selama 3 tahun (tahun $2014 \mathrm{~s} / \mathrm{d}$ 2016) untuk variabel dependen (Y), maka diperoleh sebanyak 69 × $3=207$ data pengamatan menjadi 162 data pengamatan, karena ada data yang tidak normal.

\section{Hasil Penelitian \\ Statistik Deskriptif}

Statistik deskriptif memberikan gambaran tentang data sampel yang digunakan dalam penelitian ini, sehingga dapat memperlihatkan nilai minimum, nilai maksimum, nilai rata-rata (mean) dan standar deviasi dari masing-masing variabel independen yaitu variabel Earning Management, Leverage, Size dan Capital Intensity. Berdasarkan hasil statistik deskriptif menunjukkan bahwa variabel Earning Management, Leverage, Size dan Capital Intensity menunjukkan terhadap perusahaan-perusahaan yang terdeteksi melakukan tindakan penghindaran pajak.

\section{Uji Normalitas}

Berdasarkan hasil uji normalitas dengan menggunakan One Sample Kolmogorov Smirnov Test menunjukkan hasil signifikansi $0,164<0,05$, maka dapat disimpulkan data berdistribusi normal.

\section{Uji Asumsi Klasik}


Hasil pengujian asumsi klasik dalam penelitian ini telah memenuhi persyaratan data yang baik untuk diolah. Data memenuhi uji normalitas dan terbebas dari multikolineritas, autokorelasi, serta heterokedastisitas. Model regresi yang digunakan untuk menganalisis pengaruh manajemen laba dan karakteristik perusahaan terhadap tax avoidance dapat dinyatakan bahwa model regresi adalah layak untuk dipakai.

\section{Uji Statistik F}

Uji statistik F pada dasarnya menunjukkan apakah semua variabel independen atau bebas yang dimasukkan dalam model mempunyai pengaruh secara bersama-sama terhadap variabel dependen/terikat (Ghozali, 2012:98). Uji statistik F digunakan untuk menguji kelayakan model regresi. Dasar pengambilan keputusan untuk pengujian secara simultan ini adalah dengan membandingkan $p$-value dengan $\alpha$ sebesar 0,05. Jika $p$-value < alpha 0,05 maka Ho ditolak dan sebaliknya jika $p$-value > alpha 0,05 maka Ho diterima. Berdasarkan hasil signifikansi yang ditunjukkan sebesar $0,003<0,05$ bahwa Ho ditolak atau Ha diterima yang berarti bahwa variabel independen Manajeman Laba dan Karakteristik Perusahaan (Leverage, Size, dan Capital Intensity) secara simultan berpengaruh signifikan terhadap variabel dependen Tax Avoidance.

\section{Uji Statistik t.}

Uji Statistik t pada dasarnya menunjukkan seberapa jauh pengaruh satu variabel penjelas/independen secara individual dalam menerangkan variasi variabel independen (Ghozali, 2012:98). Penentuan keputusan untuk menerima atau menolak hipotesis adalah nilai signifikansi lebih kecil 0,05 maka Ho ditolak dan Ha diterima, dengan kata lain dapat disimpulkan bahwa variabel bebas tersebut secara individu mempunyai pengaruh yang signifikan terhadap variabel terikat.

Tabel 1. Hasil Uji t

\begin{tabular}{clccc}
\multicolumn{5}{c}{ Sumber: Hasil Pengolahan Data } \\
\hline Model & Variabel & Coeficient & Sig. & Keputusan Ho \\
\hline ETR & Constant & 0,212 & 0,000 & - \\
& EM & $3,722 \mathrm{E}-007$ & 0,478 & Di terima \\
& LEV & 0,079 & 0,000 & Ditolak \\
& SIZE & 0,000 & 0,878 & Diterima \\
& CAP & 0,012 & 0,595 & Diterima \\
\hline
\end{tabular}

Berdasarkan hasil uji partial test pada Tabel 1, maka dapat dinyatakan model regresi dalam penelitian ini sebagai berikut:

$\mathrm{ETR}=0,212+3,722 \mathrm{E}-007(\mathrm{EM})+0,079(\mathrm{LEV})+0,000(\mathrm{SIZE})+0,012(\mathrm{CAP})+\mathrm{e}$

Keterangan: ETR = Effective Tax Rate untuk variabel Tax Avoidance

$$
\begin{aligned}
& \mathrm{EM}=\text { Earnings Management } \\
& \mathrm{LEV}=\text { Leverage } \\
& \mathrm{SIZE}=\text { Size } \\
& \mathrm{CAP}=\text { Capital Intensity } \\
& \alpha \quad=\text { Konstanta; } \\
& \mathrm{e} \quad=\text { Error }
\end{aligned}
$$

Interpretasi atas hasil persamaan regresi $1 \mathrm{~s} / \mathrm{d} 4$ di atas menunjukkan bahwa semakin tinggi nilai Earning Managements, Leverage, Size, dan Capital Intensity perusahaan manufaktur yang terdaftar di Bursa Efek Indonesia, maka probabilitas perusahaan manufaktur melakukan Tax Avoidance juga semakin tinggi. 


\section{Uji Koefisien Determinasi.}

Hasil uji koefisien determinasi menunjukkan Nilai R yang berarti hubungan Manajemen Laba dan Karakteristik Perusahaan terhadap Tax Avoidance adalah lemah. Nilai adjusted $R$ square sebesar 0,098, angka ini menunjukkan Manajemen Laba dan Karakteristik Perusahaan kurang mampu menjelaskan variasi dari variabel Tax Avoidance. Untuk Nilai adjusted $R$ square sebesar 0,075, angka ini menunjukkan bahwa sebesar 7,5\% dari Tax Avoidance dapat dijelaskan oleh Manajemen Laba dan Karakteristik Perusahaan (Leverage, Size, dan Capital Intensity) sedangkan sisanya dijelaskan oleh variabel lain diluar penelitian ini.

\section{Pembahasan Penelitian}

Hasil pengujian hipotesis pertama menunjukkan bahwa variabel Manajemen Laba memiliki signifikansi 0,478 terhadap Tax Avoidance. Hasil ini menunjukkan bahwa variabel Manajemen Laba tersebut secara statistik tidak berpengaruh terhadap Tax Avoidance. Hasil penelitian ini tidak mendukung hasil penelitian Badertsche, et al. (2009) yang menunjukkan praktek manajemen laba dilakukan oleh perusahaan sebagai alat untuk melakukan penghindaran regulasi pemerintah (political cost hypothesis). Salah satu regulasi pemerintah yang berkaitan langsung dengan laba perusahaan adalah pajak penghasilan badan. Pengaruh manajemen laba berupa income decreasing terhadap agresivitas pajak dengan proksi effective tax rate dapat dijelaskan bahwa laba menjadi patokan untuk mengukur beban pajak perusahaan. Oleh karena itu, manajemen akan melaporkan laba disesuaikan dengan tujuannya yaitu menggunakan pilihan akuntansi yang mengurangi laba atau income decreasing sebagai bentuk penghindaran pajak (Suryanto \& Supramono, 2012). Hal ini dapat disimpulkan bahwa hipotesis pertama menunjukkan Manajemen Laba tidak berpengaruh signifikan secara statistik terhadap Tax Avoidance, dimana semakin besar income decreasing yang dilakukan perusahaan, maka perusahaan tersebut tidak terindikasi melakukan penghindaran pajak.

Hasil pengujian hipotesis kedua menunjukkan bahwa variabel Leverage memiliki signifikansi 0,000 terhadap Tax Avoidance. Hasil ini menunjukkan bahwa variabel Leverage tersebut secara statistik berpengaruh positif terhadap Tax Avoidance. Hasil penelitian ini mendukung secara positif hasil penelitian Siregar dan Widyawati (2016), Dewi, et al. (2016), serta Dharma dan Adriana (2016). Perusahaan manufaktur yang memanfaatkan hutang untuk meminimalkan beban pajak perusahaan bahkan cenderung mengarah agresif terhadap pajak, hal ini dikarenakan perusahaan yang memiliki utang tinggi akan mendapatkan insentif pajak berupa potongan atas bunga pinjaman. Sehingga perusahaan yang memiliki beban pajak tinggi dapat melakukan penghematan pajak dengan cara menambah hutang perusahaan. Hal ini dapat disimpulkan bahwa hipotesis kedua menunjukkan Leverage berpengaruh signifikan secara statistik terhadap Tax Avoidance, dimana penambahan hutang guna memperoleh insentif pajak yang besar maka dapat dikatakan bahwa perusahaan tersebut melakukan penghindaran terhadap pajak. Semakin tinggi leverage perusahaan maka semakin tinggi tindakan penghindaran pajaknya.

Hasil pengujian hipotesis ketiga menunjukkan bahwa variabel Size memiliki signifikansi 0,878 terhadap Tax Avoidance. Hasil ini menunjukkan bahwa variabel Size tersebut secara statistik tidak berpengaruh terhadap Tax Avoidance. Hasil penelitian ini tidak mendukung hasil penelitian Darmawan dan Sukartha (2014), Ngadiman dan Puspitasari (2014), Siregar dan Widyawati (2016), Dharma dan Adriana (2016), serta Putra dan Merkusiwati (2016) menunjukkan hasil variabel Size berpengaruh positif terhadap Tax Avoidance. Perusahaan yang melakukan tax avoidance adalah perusahaan yang menghadapi political power theory karena mempunyai sumber daya yang mecukupi untuk memanfaatkan proses politik yang dapat menguntungkan mereka dan melakukan aktivitas perencanaan pajak yang agresif dengan tujuan mendapatkan 
penghematan pajak melalui penghindaran pajak yang dilakukan. Hal ini dapat disimpulkan bahwa hipotesis ketiga menunjukkan Size tidak berpengaruh signifikan secara statistik terhadap Tax Avoidance, dimana semakin besar Size atau ukuran perusahaan, maka tidak mengindikasikan perusahaan melakukan penghindaran pajak. Ukuran perusahaan yang besar belum tentu melakukan penghindaran pajak, karena perusahaan kecil atau menengah pun dapat melakukan penghindaran pajak, namun jumlahnya masih kecil dan tidak terlalu menjadi perhatian fiskus, sehingga perusahaan yang melakukan penghindaran pajak menyebar ke seluruh ukuran perusahaan.

Hasil pengujian hipotesis keempat menunjukkan bahwa variabel Capital Intensity memiliki signifikansi 0,595 terhadap Tax Avoidance. Hasil ini menunjukkan bahwa variabel Capital Intensity tersebut secara statistik tidak berpengaruh terhadap Tax Avoidance. Hasil penelitian ini tidak mendukung hasil penelitian Dharma dan Ardiana (2016), aset tetap perusahaan memiliki umur ekonomis yang berbeda-beda apabila dilihat dari perpajakan Indonesia. Aset tetap tersebut juga memiliki beban depresiasi yang berbeda. Oleh karena itu, capital intensity berpengaruh positif terhadap tax avoidance, dikarenakan intensitas aset tetap berpengaruh positif terhadap effective tax rate (ETR). Hal ini dapat disimpulkan bahwa hipotesis keempat menunjukkan Capital Intensity tidak berpengaruh signifikan secara statistik terhadap Tax Avoidance, dimana semakin besar intensitas aset tetap maka perusahaan tidak terindikasi melakukan penghindaran pajak. Perusahaan yang mempunyai aset tetap yang tinggi menunjukkan penggunaan aset tetap yang tinggi dikarenakan untuk kepentingan operasional dan investasi yang dilakukan perusahaan dan bukan untuk mengindikasikan perusahaan melakukan penghindaran pajak, sehingga aset tetap yang tinggi ini tidak mempengaruhi tingkat penghindaran pajak yang dilakukan oleh perusahaan.

\section{KESIMPULAN DAN SARAN}

\section{Kesimpulan}

Penelitian ini merupakan penelitian yang memberikan jawaban mengenai pengaruh manajemen laba dan karakteristik perusahaan terhadap tax avoidance. Dari empat variabel independen yang diteliti yaitu manajemen laba, leverage, size dan capital intensity, hanya variabel leverage yang berpengaruh positif terhadap tax avoidance pada perusahaan manufaktur periode 2014-2016, dimana penambahan hutang guna memperoleh insentif pajak yang besar maka dapat dikatakan bahwa perusahaan tersebut melakukan penghindaran terhadap pajak. Semakin tinggi leverage perusahaan maka semakin tinggi tindakan penghindaran pajaknya. Penelitian ini memiliki keterbatasan. Pertama, penelitian ini tidak memasukkan seluruh perusahaan yang terdaftar di Bursa Efek Indonesia. Kedua, penelitian ini hanya menggunakan variabel manajemen laba dan karakteristik perusahaan dalam menguji berpengaruhnya terhadap Tax Avoidance.

\section{Saran}

Atas dasar keterbatasan penelitian di atas, maka untuk penelitian selanjutnya disarankan: Pertama, memasukkan seluruh perusahaan yang terdaftar di Bursa Efek Indonesia sehingga hasil penelitiannya dapat digeneralisasi dan lebih komprehensif. Kedua, penelitian berikutnya dapat menambahkan faktor yang lain seperti corporate governance, struktur kepemilikan dan penggunaan derivatif keuangan sehingga hasil penelitian lebih tepat.

\section{Ucapan Terima Kasih (Acknowledgement)}

Terima kasih kepada Direktorat Penelitian dan Pengabdian kepada Masyarakat (DPPM) Universitas Tarumanagara yang telah memberikan kontribusi dana, dan asisten peneliti yang telah memberikan kontribusi dalam input data yang bermakna bagi penelitian ini. 


\section{REFERENSI}

Badertscher, B. A., Phillips J. D., Pincus, M. \& Rego, S. O. (2009). Earnings Management Strategies and the Trade-Off between Tax Benefits and Detection Risk: To Conform or Not to Conform?. The Accounting Review, 84(1), 63-77.

Daito, A. (2011). Pencarian Ilmu Melalui Pendekatan: Ontologi, Epistemologi, Aksiologi. Jakarta: Penerbit Mitra Wacana Media.

Darmawan, I. G. H. \& Sukartha, I. M. (2014). Pengaruh Penerapan Corporate Governance, Leverage, Return on Assets, dan Ukuran Perusahaan pada Penghindaran Pajak. E-Jurnal Akuntansi Universitas Udayana, 9(1), 143-161.

Dechow, P. M., Sloan, R. G. \& Sweeney, A. P. (1995). Detecting Earnings Management. The Accounting Review, 70(2), 193-225.

Dewi, N. N. K. \& Jati, I. K. (2014). Pengaruh Karakteristik Eksekutif, Karakteristik Perusahaan, dan Dimensi Tata Kelola Perusahaan yang Baik pada Tax Avoidance di Bursa Efek Indonesia. E-Jurnal Akuntansi Universitas Udayana, 6(2), 249-260.

Dewi, N., Nasir, A. \& Hariadi. (2016). Pengaruh Karakteristik Eksekutif, Karakteristik Perusahaan, dan Pengungkapan Tanggung Jawab Sosial Perusahaan terhadap Penghindaran Pajak (Studi Empiris Perusahaan Pertambangan yang Terdaftar di BEI 2011-2013). JOM Fekon, 3(1), 1006-1020.

Dharma, I. M. S. \& Ardiana, P. A. (2016). Pengaruh Leverage, Intensitas Aset Tetap, Ukuran Perusahaan, dan Koneksi Politik Terhadap Tax Avoidance. E-Jurnal Akuntansi Universitas Udayana, 15(1), 584-613.

Ghozali, I. (2012). Aplikasi Analisis Multivariate dengan Program IBM SPSS 20. Edisi 6. Semarang: Badan Penerbit Universitas Diponegoro.

Gupta, S. \& Newberry, K. (1997). Determinants of the Variability in Corporate Effective Tax Rate: Evidence from Longitudinal Data. Journal of Accounting and Public Policy, 16, 134.

Jensen, M. \& Meckling, W. (1976). Theory of the Firm: Managerial Behavior, Agency Cost and Ownership Structure. Journal of Financial Economic, 3(4), 305-360.

Meek, G. K. \& Gray, S. J. (1988). The Value Added Statement: An Innovation for The US Companies. Accounting Horizons, 12(2), 73-81.

Ngadiman \& Puspitasari C. (2014). Pengaruh Leverage, Kepemilikan Institusional, dan Ukuran Perusahaan terhadap Penghindaran Pajak (Tax Avoidance) pada Perusahaan Sektor Manufaktur yang Terdaftar di Bursa Efek Indonesia 2010-2012. Jurnal Akuntansi, 18(3), 408-421.

Putra, I. G. L. N. D. C \& Merkusiwati, N. K. L. A. (2016). Pengaruh Komisaris Independen, Leverage, Size dan Capital Intensity Ratio pada Tax Avoidance. E-Jurnal Akuntansi Universitas Udayana, 17(1), 690-714.

Scott, W. R. (2015). Financial Accounting Theory. Seventh Edition. United States of America: Pearson Canada Inc.

Sekaran, U. (2008). Research Methods For Business, A Skill Building Approach. $4^{\text {th }}$ Edition. New York: John Wiley \& Sons.

Siregar, R. \& Widyawati, D. (2016). Pengaruh Karakteristik Perusahaan Terhadap Penghindaran Pajak Pada Perusahaan Manufaktur di BEI. Jurnal Ilmu dan Riset Akuntansi 5 (2): 1-16.

Suyanto, K. D. \& Supramono. (2012). Likuiditas, Leverage, Komisaris Independen, dan Manajemen Laba terhadap Agresivitas Pajak Perusahaan. Jurnal Keuangan dan Perbankan 16 (2): 167-177.

Watts, R. L., \& Zimmerman, J. L. (1986). Positive Accounting Theory. New Jersey: Practice Hall, Inc. 